\title{
Cardiovascular Drugs and Erectile Dysfunction
}

\author{
Branka M. Terzić1 ${ }^{1}$ Srdjan Z. Marković , Jelena Dj Grujićs \\ Ljiljana C. Djukić ${ }^{4}$ \\ ${ }^{1}$ Clinical Center of Serbia, Belgrade \\ ${ }^{2}$ Medical Faculty, University of Belgrade, Belgrade, Serbia \\ ${ }^{3}$ Serbian Ministry of Agriculture and Environmental Protection \\ ${ }^{4}$ Agency for drugs and medical devices ALIMS, Belgrade, Serbia
}

\section{SUMMARY}

Erectile dysfunction (ED) is a disorder, which basically can have organic nature, psychological or mixed. ED is not a rarity, and data on its prevalence vary, depending on the areas in which the survey was conducted, followed by a period of research and the definition of the disorder. Most of the men associate ED problem with using drugs, especially cardiac. Even though there is some truth in it, mainly the real causes of ED are not well known even to professionals.

Contemporary studies of risk factors for cardiovascular disease, particularly coronary heart disease, have shown the clear link between erectile dysfunction and coronary heart disease, wherein ED first manifests. While, ED precedes the onset of symptoms of coronary heart disease and show to the patient and the physician a clear signal of the direction for conducting diagnostic tests and further treatment in the interest of the health of patients. Endocrine, and neurological disorders, as well as bad habits in addition to the cardiac and kidney disease, lead to ED.

It is known also, that the use of cardiac medicines may contribute to ED occurrence. Better knowledge of adverse reactions to medicines, a better understanding of the nature of the disease and the implementation of necessary diagnostic procedures, with a good choice of medication, contribute to solving problems related to ED. If all mentioned do not help, there is the possibility of using new drugs to correct ED.

Keywords: erectile dysfunction, coronary heart disease, cardiovascular drugs 


\section{INTRODUCTION}

Male sexual potency (potency) is a complex phenomenon and includes libido, erection and orgasm. Each of the components of the sexual power of a man can be damaged permanently or temporarily and lead to impotence. It is known from ancient times that people tend to find a means to enhance potency, which in practical application, but non-medical, has introduced a range of products, herbal remedies, various resources, many toxic substances, including the fragmented parts of rhinoceros horn, because of the belief that they can be useful. Erectile dysfunction is one of the problems which is connected to the potency of men and is defined as the inability to achieve sufficient erection, the required ratio of sexualintercourse.

It is a known fact that many cardiovascular (CV) drugs may adversely affect the potency and with different mechanisms [1]. Less is known that cardiac and other diseases cause erectile dysfunction and impotence, especially heart failure, hypertension, diabetes mellitus, renal failure, and other organic states. It is important to emphasize and clarify that CVdrugs, applied on time may prevent the development of cardiovascular CVD thereby reducing the risk of erectile dysfunction (ED). ED usually precedes CVD onset, and it might be considered an early marker of symptomatic CVD $[2,3]$.

\section{EPIDEMIOLOGICAL DATA ON THE INCIDENCE OF ERECTILE DYSFUNCTION}

From 18 to 50 million Americans have occasional or frequent erectile dysfunction, then about $12 \%$ to $18 \%$ of Europeans, or 100 million people in the world, $[4,5,6,7,8]$. Age over 50 years contributes to the development of ED [9], hypertension, hypercholesterolemia, diabetes mellitus, metabolic syndrome, insulin resistance, renal failure, and stroke. It should be emphasized that coronary heart disease and ED share common risk factors, or other authors [6] who consider that ED is predictive for the development of coronary artery disease and acute myocardial infarct.

\section{THE STRUCTURES IN THE BODY RESPONSIBLE FOR THE POTENCY}

While libido is related to CNS function, ejaculation requires an intact sympathetic motor function. Orgasm involves conserve - independent superficial and deep sensibility while erection phenomenon is directly dependent on the vascular system. The outcome of trabecular smooth muscle relaxation inside of corpora cavernosa is that sinuses are overloaded with blood which causes erection [10]. Knowledge of the physiological phenomenon has led to the discovery of medecines for the ED (sildenafil citrate, tadalafil, vardenafil hydrochloride). A good function of the CNS and spinal cord, pelvic vegetative nervous system, as well as a normal function of the cardiovascular system, especially in preserved blood circulation of aorta, iliac or other pelvic arteries, are necessary for the achievement of potency.

\section{NEUROTRANSMITTERS AND MODULATORS FOR THE MALE SEXUAL FUNCTION ACHIEVEMENT}

NO release [11] from the non-adrenergic and non-cholinergic nerves and the release of prostaglandins and cGMP are necessary for an erection in physiological conditions. For relaxation of the cavernous bodies are required: acetylcholine, nitric oxide (NO), vasoactive intestinal polypeptide, pituitary adenylyl cyclaseactivating peptide, calcitonin, adrenomedullin, ATP, adenosine, prostanoids. The contraction of the corpora cavernosa of the body requires: noradrenaline, endothelin-1, neuropeptide $\mathrm{Y}$, prostanoids and angiotensin II.

\section{CAUSES OF IMPOTENCE}

Causes of impotence can be organic and psychological in nature, or mixed. The most common causes of organic impotence are vascular, hormonal and neurogenic nature [5]. When it comes to vascular genesis of ED, it is due to endothelium damage, lacking endotheliumdependent relaxation of smooth muscles in cavernous bodies, causing decreased blood flow to the cavernous sinus. Also, there may be up to the structural and atherosclerotic lesions, within the blood vessel through which blood flows in the corpora cavernosa, causing 
ED. Some neurological diseases that occur due to damage to the pelvic nerves (multiple sclerosis, Parkinson's disease, stroke), can be a cause of ED [12].

\section{ERECTILE DYSFUNCTION AND CARDIAC DISEASES}

A number of diseases and conditions of the cardiovascular system lead to the ED, such as hypertension, cardiac insufficiency, atherosclerotic peripheral arterial disease, vascular endothelial injury, etc. [13]. It is important to emphasize the fact that the Serbian medicine still neglects that the ED is manifested in patients with coronary heart disease before the manifestation of symptoms of coronary artery disease and that certainly deserves attention and care of physicians, because it is the alarm that indicates a potential for serious and fatal complications of coronary disease [5]. In patients with ED stroke is $10 \%$ more common, acute myocardial infarction is twice as common. In addition, hospitalization in patients with ED due to heart failure is $20 \%$ more often. Therefore, a questionnaire on ED it should be prepared to fill in for all cardiac patients over 50 years who are coming to a cardiologist, as it has been common in many European countries [5].

\section{DIABETES MELLITUS AND ERECTILE DYSFUNCTION}

One of the most common causesof ED is diabetes mellitus that causes damages in blood vessels and in nerves [14] which significantly affects the occurrence of ED in these patients. ED in men with diabetes is three times more frequent than in other men of the same age, and during monitoring phase of diabetic patients ED was observed in 33\% of diabetic patients, and as many as $50 \%$ of respondents had occasional ED [14]. Predisposing factors for ED in diabetic patients are older age, smoking, obesity and poor blood glucose control.

\section{THE IMPORTANCE OF ENDOTHELIAL DYSFUNCTION FOR ERECTILE DYSFUNCTION}

There are numerous data linking endothelial dysfunction $[15,16]$, inflammatory processes in blood vessels and ED. ED and pathophysi- ological changes in coronary blood vessels are connected with the same mechanism, but because of the smaller diameter of penile blood vessels, a process of endothelial dysfunction leads earlier to the ED, than to the manifestations of coronary heart disease $[5,6]$.

\section{OTHER CONDITIONS AND DISEASES ASSOCIATED WITH ERECTILE DYSFUNCTION}

In addition to these diseases the occurrence of ED particularly affects chronic renal failure, cirrhosis of the liver, epilepsy, scleroderma, slip apnea, spinal trauma, and smoking, consumption of large quantities of alcohol, abdominal obesity, and physical inactivity, hormonal disorders (hypogonadism), thyroid gland dysfunction, prostate problems and especially surgical prostatectomy. Radiation therapy of pelvic region is associated with $\mathrm{ED}$, due to damage of pelvic nerves and blood vessels, which are important for the function of potency [17]. Also, depression in men may be accompanied by ED [18], and a treatment of depression may correct ED. Men over 70 years old have the most frequent problems with potency [6].

\section{MECHANISMS OF ACTION OF CARDIOVASCULAR DRUGS AND ERECTILE DYSFUNCTION}

The level of activity of the sympathetic nervous system is of great importance for the function of CVS, and potency (libido, erection and orgasm). Given that a large number of cardiac medications reduce the increased sympathetic activity, it is not unexpected that these CV drugs can adversely affect the potency [19]. Thus, for example, the reduction of libido, CV drugs influence acting on the Sympathicus depressant, such as e.g. reserpine, alpha methyl dopa and clonidine [20] and it is one of the reasons why these drugs are now rarely used in the treatment of hypertension. Furthermore, many antihypertensive drugs lead to ED and the weakening of potency (some beta-blockers, calcium antagonists, alpha-blockers, diuretics) which can often be the reason for hypertension treatment cancellation $[4,6]$. Good cooperation with patients and an adequate selection of other drugs is necessary, since the development of endothelial dysfunction and 
ED are conditioned by hypertension treatment omission.

\section{DRUGS AND POTENCY}

Potency and ED can affect many drugs, especially drugs that act on the central nervous system: neuroleptics, sedatives, anticonvulsants, some antidepressants. Then, also cimetidine, finasteride, anti-androgenic drugs but rarely any other drugs [21]. However, it has been reported that statin therapy may reduce levels of testosterone and aggravate symptoms of ED [22].

\section{ANTIHYPERTENSIVE AND ERECTILE DYSFUNCTION}

Diuretics (thiazides, Henley's loop diuretics) reduce the response of a tissue to catecholamines and cause ED. Spironolactone has anti-androgen side effect, which is the reason for the appearance of ED. In a prospective clinical study with high-risk hypertensive patients, the use of diuretics, $\mathrm{Ca}$ antagonists and beta blockers has often caused ED [6]. Among the tested beta blockers, which are especially important in the treatment of hypertensive patients with coronary artery disease, bisoprolol, atenolol, carvedilol and metoprolol were the reason of expressed ED in $13 \%$ to $28 \%$ of patients. The smallest impact on ED showed nebivolol (10\%), most likely due to more complex mechanism of action of nebivolol and positive effect on NO synthesis $[4,6]$, which is important for endothelial function.

\section{LABORATORY TESTS IN THE ERECTILE DYSFUNCTION}

A detailed analysis of risk factors for cardiovascular disease is required in patients with ED. Those who are associated with cardiovascular disease or diabetes are considered highrisk patients with ED. Patients with low risk should undertake further examination, such as laboratory tests: blood glucose, cholesterol, uric acid, checking kidney and liver functions, urinalysis, control of blood pressure, ECG, but also other cardiac tests for exclusion of cardiovascular disease, as well as endocrine tests [4].

\section{PREVENTION OF ERECTILE DYSFUNCTION}

Prevention of ED involves the optimal treatment of hypertension and other cardiac disease, the optimal treatment of diabetes, hyperlipidemia, and limited alcohol intake. Then, modification of lifestyle, which allows preservation of blood vessels, such as smoking cessation, regular physical activity, a Mediterranean diet, maintaining ideal body weight and periodic health exams at the doctor.

\section{CONCLUSIONS}

If psychogenic ED character of men over 50 years is excluded, ED should be considered as a serious cardiac illnesses, equivalent to coronary heart disease. Accordingly, there is need for additional diagnostic testing both cardiac and endocrine. If the patient is on therapy, a contribution of drugs to the development of ED should be considered. Today there is a large number of cardiac drugs, so there is always an alternative choice. Patients should be familiarized with the nature of the problem of ED and persuaded that the use drugs in the treatment of cardiovascular disease, changes in lifestyle and diet have a positive effect on ED. If this does not help it should be considered to use drugs in the treatment of $\mathrm{ED}$, taking into account the risks of the interaction with cardiac therapy (nitrates).

\section{REFERENCES}

1. Alberto Cordero A, Bertomeu-Martınez V, Mazon P, Facila L, Bertomeu-Gonzalez V, Conthe P, Gonzalez J. Erectile Dysfunction in High-Risk Hypertensive Patients Treated with Beta-Blockade Agents. Cardiovascular Therapeutics. 28 (2010):15-22.

2. Gandaglia G, Briganti A, Jackson G, Kloner RA, Montorsi F, Montorsi P, Vlachopoulos C. A Systematic Review of the Association between Erectile Dysfunction and Cardiovascular Disease. European Urology. 65(2014):968-978.

3. Miner MM, Kuritzky L. Erectile dysfunction: a sentinel marker for cardiovascular disease in primary care. Cleve Clin J Med. 2007;74(suppl 3):S30-S37.

4. Zanchetti A. Nebivolol, Product Monograph. Menarini investigation. 2008; 136-141.

5. Charalambos Vlachopoulos, Graham Jackson, Christodoulos Stefanadis, Piero Montorsi. Erectile dysfunction in the cardiovascular patient European. Heart Journal. 2013;34:2034-2046. 
6. Alberto Cordero A, Bertomeu-Martınez V, Mazon P, Facila L, Bertomeu-Gonzalez V, Conthe P, Gonzalez J. Erectile Dysfunction in High-Risk Hypertensive Patients Treated with Beta-Blockade Agents. Cardiovascular Therapeutics. 2010(28):15-22.

7. Bacon CG, Mittleman MA, Kawachi I, Giovannucci $E$, Glasser DB, Rimm EB. Sexual function in men older than 50 years of age: results from the health professional's follow-up study. Ann Intern Med. 2003;139(3):161-168.

8. Dieterle T. Erectile dysfunction in arterial hypertension. Cardiovascular Medicine. 2014;17(3):8284.

9. Shi JP, Zhao YM, Song YT. Effect of aging on expression of nitric oxide synthase I and activity of nitric oxide synthase in rat penis. Asian J Androl. 2003;5:117-20.

10. Lewis JH, Rosen R, Goldstein I. The consensus panel on health care clinician management of erectile dysfunction. Erectile dysfunction: a panel's recommendations for management. Am $\mathrm{J}$ Nurs. 2003;103:48-57.

11. Burnett AL, Lowenstein CJ, Bredt DS, Chang TS, Snyder TS. Nitric oxide: a physiological mediator of penile erection. Science. 1992;257:401-3.

12. Althof SE, Seftel AD. The evaluation and management of erectile dysfunction. Psychiatr Clin North Am. 1995;18(1):171-92.

13. Rosen RC, Jackson G, Kostis JB. Erectile dysfunction and cardiac disease: recommendations of the Second Princeton Conference. Curr Urol Rep. 2006;7(6):490-6.

14. Miner $M$, Seftel $A D$, Nehra A, Ganz P, Kloner RA, Montorsi P, Vlachopoulus C, Remsey M, Sigman $M$, Tilkemeier P, Jackson G. Prognostic utility of erectile dysfunction for cardiovascular disease in younger men and those with diabetes. Am Heart J. 2012;164(1):21-8.

15. Vlachopoulos C, Aznaouridis K, loakeimidis N, Rokkas K, Tsekoura D, Vasiliadou C, Stefanadi E, Askitis A, Stefanadis C. Arterial function and intimamedia thickness in hypertensive patients with erectile dysfunction. J Hypertens. 2008;26:18291836.

16. Vlachopoulos C, Aznaouridis K, loakeimidis N, Rokkas K, Vasiliadou C, Alexopoulos N, Stefanadi E, Askitis A, Stefanadis C. Unfavourable endothelia and inflammatory state in erectile dysfunction patients with or without coronary artery disease. Eur Heart J. 2006;27:2640-2648.

17. Larson TR. Current treatment options for benign prostatic hyperplasia and their impact on sexual function. Urology. 2003;61(4):692-8.

18. Araujo AB, Durante R, Feldman HA, Goldstein I, McKinlay JB. The relationship between depressive symptoms and male erectile dysfunction: crosssectional results from the Massachusetts Male Aging
Study. Psychosom Med. 1998;60(4):458-65.

19. Heidelbaugh JJ. Management of erectile dysfunction. American Family Physician, February 1, 2010, 81( 3 ); www.aafp.org/afp.

20. Smith PJ, Talbert RL. Sexual dysfunction with antihypertensive and antipsychotic agents. Clin Pharm. 1986;5(5):373-84.

21. Nicolai MPJ, Liem SS, Both S, Pelger RCM, Putter $\mathrm{H}$, Schalij MJ, Elzevier HW. A review of the positive and negative effects of cardiovascular drugs on sexual function: a proposed table for use in clinical practice. Neth Heart J. 2014;22:11-19.

22. Cai X, Tian Y, Wu T, Cao CX, Bu SY, Wang KJ. The role of statins in erectile dysfunction: a systematic review and meta-analysis. Asian J Androl. 2014. doi10.4103/1008-682X.123678. [Epub ahead of print] 


\title{
Kardiovaskularni lekovi i erektilna disfunkcija
}

\author{
Branka M. Terzić ${ }^{1}$, Srdjan Z. Marković ${ }^{2}$ Jelena Dj Grujić ${ }^{3}$, Ljiljana C. Djukić ${ }^{4}$ \\ ${ }^{1}$ Klinički centar Srbije, Beograd, Srbija. \\ ${ }^{2}$ Medicinski fakultet, Univerzitet u Beogradu, Srbija \\ ${ }^{3}$ Ministarstvo poljoprivrede i zaštite životne sredine Republike Srbije, Beograd, Srbija \\ ${ }^{4}$ Agencija za lekove i medicinska sredstva (ALIMS), Beograd, Srbija.
}

\section{KRATAK SADRŽAJ}

Erektilna disfunkcija (ED) je poremećaj, koji u osnovi može biti organske, psihičke prirode, ili mešovite. ED nije retkost, a podaci o njenoj učestalosti variraju, zavisno od područja u kome je istraživanje sprovedeno, zatim od perioda istraživanja $i$ definisanja samog poremećaja. Većina muškaraca vezuje problem ED sa primenom lekova, posebno kardioloških. Mada u tome ima istine, uglavnom pravi uzroci ED nisu dovoljno poznati čak ni stručnoj javnosti.

Savremena istraživanja faktora rizika za kardiovaskularne bolesti, posebno za koronarnu bolest srca, pokazala su postojanje jasne veze između erektilne disfunkcije i koronarne bolesti srca, pri čemu je ED prva manifestacija. ED prethodi pojavi simptoma koronarne bolesti srca i predstavlja jasan signal za bolesnika i za lekara u kom smeru treba sprovesti dijagnostička ispitivanja i dalje lečenje u interesu zdravlja bolesnika. Pored kardioloških i bolesti bubrega, endokrine i neurološke bolesti, kao i loše životne navike mogu da dovedu do ED.

Poznato je takođe da primena kardioloških lekova može da doprinese pojavi ED. Bolje poznavanje neželjenih reakcija lekova, bolje poznavanje prirode bolesti i sprovođenje potrebnih dijagnostičkih procedura, uz dobar izbor lekova, doprinosi rešavanju problema vezanih za ED. Ukoliko sve to ne pomogne, postoji mogućnost primene novih lekova za korekciju ED.

Ključne reči: erektilna disfunkcija, koronarna bolest srca, kardiovaskularni lekovi 